\title{
ANALISIS PENDAPATAN PETANI BUNGA POTONG KRISAN DAN FAKTOR - FAKTOR YANG MEMPENGARUHI PENDAPATAN ANGGOTA KELOMPOK TANI DAN BUKAN ANGGOTA KELOMPOK TANI
}

\author{
(Analysis Of Chrysanthemum Cut Flower Farmer Income And Factors Affect The Income Of \\ Members Of Farmer Group And Non-Farmer Group)
}

\author{
Selfiana \\ Fakultas Pertanian dan Bisnis, Universitas Kristen Satya Wacana Salatiga \\ J1. Diponegoro No.52-60, Salatiga, Kecamatan Sidorejo, Kota Salatiga, Jawa Tengah 50711
}

(Email: 522013018@student.uksw.edu)

Article Submitted : 15-5-2020

Article Accepted : 07-6-2020

\begin{abstract}
Chrysanthemum (Chrysanthemum) is an ornamental plant that has good prospects and potential for cultivation in Indonesia. In addition to diverse shapes and types, the color of flowers is very varied and attractive so that market demand both domestically and abroad is increasing every year (Lukito, 1998). The purpose of this study is to determine the income of farmers who are members of farmer groups and not members of farmer groups and determine the influence of farmer group membership factors and non-members of farmer groups, land area, selling price, education level, number of workers, number of family members to farmers' income. This research was conducted in Clapar Hamlet, Duren Village, Bandungan District, Semarang Regency. This research is a quantitative descriptive study with a sampling method using accidental sampling and snowball sampling with 33 respondents. The data analysis technique used Microsoft Excel 2007 and SPSS 20. The results showed that the income received by farmers belonging to farmer groups was $\mathrm{Rp} 220,794,486$ / ha and the income received from non-farmer groups was Rp 152,877,569 / ha. The area of land area and selling price have a significant effect on the income of farmers, while the factors of membership of farmer groups and non-members of farmer groups, level of education, number of workers, number of family members have no significant effect on farmer income.
\end{abstract}

Keywords: Acceptance; income; cost; factors of production, farming.

\section{PENDAHULUAN}

Krisan (Chrysanthemum) adalah salah satu tanaman hias yang mempunyai prospek baik dan potensial untuk dibudidayakan di Indonesia. Selain bentuk dan tipe yang beragam, warna bunga sangat bervariasi dan menarik sehingga permintaan pasar baik dalam negeri maupun luar negeri semakin meningkat setiap tahunnya. Bunga krisan selain bisa dijual sebagai tanaman hias, bunga dalam pot juga bisa dijual sebagai bunga potong (Lukito, 1998).
Usahatani bunga potong krisan adalah salah satu kegiatan yang banyak dilakukan petani di Kecamatan Bandungan untuk memperoleh keuntungan dan meningkatkan pendapatan. Beberapa manfaat bunga potong antara lain sebagai bahan rangkaian bunga untuk berbagai keperluan mulai dari kelahiran, perkawinan, dan kematian. Oleh karena itu usahatani bunga potong mempunyai nilai ekonomi yang tinggi. (Widyawan dan Prahastuti, 1994). 
Berdasarkan BPS Provinsi Jawa Tengah Tahun 2016, Kabupaten Semarang adalah daerah dengan luas panen dan produksi tertinggi dibandingkan Kabupaten lainnya yang ada di Jawa Tengah yaitu dengan luas panen $1.872 .050 \mathrm{~m}^{2}$ dan produksi 136.149.952 tangkai. Berdasarkan BPS Kabupaten Semarang Tahun 2016, sentra bunga potong krisan adalah di Kecamatan Bandungan dengan luas panen $\left(\mathrm{m}^{2}\right)$ dan produksi (tangkai) bunga potong krisan tertinggi yaitu dengan luas panen $1.184 .500 \mathrm{~m}^{2}$,dan produksi 94.368 .000 tangkai.

Kegiatan usahatani bunga potong krisan di Kecamatan Bandungan dilakukan oleh petani yang ikut sebagai anggota kelompok tani maupun petani yang tidak ikut sebagai anggota kelompok tani. Tujuan dibentuknya kelompok tani adalah untuk lebih meningkatkan dan mengembangkan kemampuan petani dan keluarganya sebagai subyek pendekatan kelompok. Keberadaan kelompok tani diharapkan mampu memberikan jawaban atas persoalanpersoalan yang dihadapi petani sehingga pendapatan petani dapat ditingkatkan.

Salah satu masalah yang dihadapi petani bunga potong krisan adalah pendapatan yang tidak menentu dari berusahatani bunga potong krisan, sehingga peneliti tertarik ingin mengetahui berapa besar pendapatan petani bunga krisan serta apakah faktor keanggotaan kelompok tani maupun bukan kelompok tani, luas lahan, harga jual, jumlah anggota keluarga, pendidikan, tenaga kerja mempengaruhi pendapatan petani bunga potong krisan.

Berdasarkan latar belakang diatas, penelitian ini bertujuan untuk mengetahui pendapatan petani bunga potong krisan baik anggota kelompok tani maupun bukan anggota kelompok tani serta pengaruh keanggotaan kelompok tani dan bukan kelompok tani, luas lahan, harga jual, tingkat pendidikan, jumlah tenaga kerja, jumlah anggota keluarga terhadap pendapatan.

\section{METODE PENELITIAN}

\section{Waktu dan Tempat Penelitian}

Penelitian dilaksanakan pada bulan Oktober - November 2018 dengan lokasi penelitian Di Dusun Clapar Desa Duren Kecamatan Bandungan Kabupaten Semarang. Penentuan lokasi penelitian dilakukan secara sengaja (purposive) dengan pertimbangan daerah yang terpilih merupakan salah satu daerah sentra produksi bunga potong krisan di Kabupaten Semarang Profinsi Jawa Tengah.

\section{Jenis dan Metode Penelitian}

Jenis penelitian yang digunakan yaitu penelitian deskriptif kuantitatif dengan metode survey. Penelitian deskriptif adalah penelitian yang dilakukan untuk mengetahui nilai variabel mandiri, baik satu variabel atau lebih tanpa membuat perbandingan dan mencari hubungan variabel itu dengan variabel yang lain (Sugiyono, 2012).

\section{Teknik Pengambilan Sampel}

Teknik pengambilan sampel dalam penelitian ini dilakukan dengan metode accidental dimana sampel dipilih karena kebetulan muncul dan dengan teknik snowball sampling dimana penentuan sampel yang mula-mula jumlahnya kecil, kemudian jumlah sampel semakin banyak ibarat bola salju yang menggelinding semakin lama semakin besar (Sugiyono, 2008)

\section{Teknik Pengumpulan Data}

Pengumpulan data pada penelitian dilakukan menggunakan dua metode yaitu data primer dan data sekunder. Data primer diperoleh melalui wawancara menggunakan instrumen kuesioner, observasi dan dokumentasi. Data sekunder diperoleh dari data yang telah diolah dan diperoleh dari instansi-instansi terkait.

\section{Teknik Analisis Data}

Analisis data yang digunakan dalam penelitian yaitu Analisis Regresi Linier Sederhana dan Analisis Usahatani. 
Pengolahan data akan dilakukan dengan menggunakan alat bantu yaitu kalkulator dan sofware komputer Microsoft Excel 2007 dan SPSS 20.

\section{Analisis Usahatani}

Usahatani adalah suatu kegiatan ekonomi yang ditujukan untuk menghasilkan output (penerimaan) dengan input fisik, tenaga kerja, dan modal. Menurut Soekartawi, et. Al, 1986, Analisis usahatani meliputi :

- Analisis Total Biaya Usahatani

Rumus : $\mathrm{TC}=\mathrm{TFC}+\mathrm{TVC}$

Keterangan:

$\mathrm{TC}=$ Total biaya usahatani (Rp)

TFC = Total biaya tetap (Rp)

TVC = Total biaya variabel $(\mathrm{Rp})$

- Analisis Penerimaan Usahatani

Rumus : TR= Py x Qy

Keterangan:

$\mathrm{TR}=$ Total penerimaan usahatani $(\mathrm{Rp})$

Py = Harga output (Rp/tangkai)

Qy = Jumlah output (tangkai)

- Analisis Pendapatan Usahatani

Rumus : $\pi=$ TR - TC

Keterangan:

$\pi=$ Pendapatan atau keuntungan usahatani (Rp)

$\mathrm{TR}=$ Total penerimaan usahatani $(\mathrm{Rp})$

$\mathrm{TC}=$ Total biaya usahatani $(\mathrm{Rp})$

\section{Analisis Regresi Linear Berganda}

Regresi linear berganda dimaksudkan untuk menguji pengaruh dua atau lebih variabel independen terhadap satu variabel dependen. Model ini mengasumsikan adanya hubungan garis lurus/linier antara variabel dependen dengan masing-masing prediktornya (Nirmala, 2012). Model regresi linear berganda yang digunakan dalam penelitian ini sebagai berikut :

$$
\begin{gathered}
Y=a+\beta_{1} X_{1}+\beta_{2} X_{2}+\beta_{3} X_{3}+\beta_{4} X_{4}+ \\
\beta_{5} X_{5}+\beta_{6} X_{6}+\varepsilon
\end{gathered}
$$

Keterangan :

$\mathrm{Y}=$ Pendapatan

$\mathrm{a} \quad=$ Konstanta

$\beta_{1} / \beta_{6}=$ 'Koefisien regresi variabel

independen

$$
\begin{array}{ll}
\mathrm{X}_{1} & =\text { Anggota kelompok tani / bukan } \\
& \text { anggota kelompok tani } \\
\mathrm{X}_{2} & =\text { Luas lahan } \\
\mathrm{X}_{3} & =\text { Harga jual } \\
\mathrm{X}_{4} & =\text { Tingkat pendidikan } \\
\mathrm{X}_{5} & =\text { Jumlah tenaga kerja } \\
\mathrm{X}_{6} & =\text { Jumlah anggota keluarga } \\
\varepsilon & =\text { Standar error }
\end{array}
$$

\section{Uji Hipotesis}

Uji Parsial (Uji t) digunakan untuk melihat pengaruh masing-masing variabel bebas (independen) secara parsial terhadap variabel terikat (dependen) (Ghozali, 2016). Uji Simultan (Uji F) digunakan untuk melihat apakah variabel bebas (independen) secara bersama-sama (serentak) berpengaruh terhadap variabel terikat (dependen). Uji kecocokan model ditolak jika $a>0,05$. Uji kecocokan model diterima jika a $<0,05$ (Sugiyono, 2012). Koefisien determiasi $\mathrm{R}^{2}$ mengukur seberapa jauh kemampuan model dalam menerangkan variabel-variabel dependen. Nilai koefisien determinasi adalah nol dan satu (Ghozali, 2016).

\section{Uji Asumsi Klasik}

Uji Normalitas Menurut (Ghozali 2016), dilakukan untuk menguji apakah dalam model regresi variabel independen dan variabel dependen atau keduanya mempunyai distribusi normal atau tidak.

Uji Multikolinieritas bertujuan untuk menguji apakah model regresi ditemukan adanya korelasi antar variabel bebas (independen).

Uji Heteroskedastisitas dilakukan untuk mengetahui apakah dalam model regresi terjadi ketidaksamaan varians dan residual suatu pengamatan ke pengamatan lain.

Uji Autokorelasi digunakan untuk mengetahui ada atau tidaknya penyimpangan asumsi klasik autokorelasi yaitu korelasi yang terjadi antara residual pada satu pengamatan dengan pengamatan lain pada model regresi. 
HASIL DAN PEMBAHASAN

\section{Variabel Penelitian}

Tabel 1. Variabel peneltian
Variabel penelitian yang digunakan dalam penelitian dapat dilihat pada tabel 1:

\begin{tabular}{llcc}
\hline No & \multicolumn{1}{c}{ Variabel Penellitian } & $\begin{array}{c}\text { Anggota } \\
\text { Kelompok Tani }\end{array}$ & $\begin{array}{c}\text { Bukan Anggota } \\
\text { Kelompok Tani }\end{array}$ \\
\hline 1. & Anggota dan bukan anggota kelompok tani (orang) & 30 & 3 \\
2. & Rata-rata luas lahan $\left(\mathrm{m}^{2}\right)$ & 1204,17 & 641,67 \\
3. & Rata-rata harga jual (Rp) & & \\
& Musim Panen 1 & 5.733 & 8.333 \\
& Musim Panen 2 & 23.433 & 18.333 \\
& Musim Panen 3 & 13.500 & 13.333 \\
4. & Tingkat pendidikan terbanyak & $\mathrm{SD}$ & $\mathrm{SD}$ \\
5. & Jumlah tenaga kerja (orang) & 2 & 1 \\
6. & Jumlah anggota keluarga rata-rata & 4 & 4 \\
\hline
\end{tabular}

Sumber : Data primer yang telah diolah (2020)

Analisis Usahatani Bunga Potong Krisan Analisis Biaya Usahatani

Biaya usahatani adalah semua biaya yang dikeluarkan petani untuk usahatani selama satu tahun. Biaya usahatani bunga potong krisan baik anggota kelompok tani dan bukan kelompok tani dapat dilihat pada Tabel 2.

Tabel 2. Rata-Rata Biaya Usahatani Usahatani Bunga Potong Krisan

\begin{tabular}{|c|c|c|c|c|}
\hline \multirow{2}{*}{$\begin{array}{c}\text { Biaya Usahatani Bunga } \\
\text { Potong Krisan } \\
\text { Per Ha }\end{array}$} & \multicolumn{2}{|c|}{ Anggota Kelompok Tani } & \multicolumn{2}{|c|}{ Bukan Anggota Kelompok Tani } \\
\hline & $\mathrm{Rp}$ & $\%$ & $\mathrm{Rp}$ & $\%$ \\
\hline \multicolumn{5}{|l|}{ A. Biaya tetap } \\
\hline - Biaya pajak lahan & 581.000 & 0,2 & 920.400 & 0,6 \\
\hline - Sewa lahan & 16.766 .000 & 8 & 0 & 0 \\
\hline $\begin{array}{l}\text { - Penyusutan alat } \\
\text { dan bangunan }\end{array}$ & 52.021 .910 & 26 & 49.332 .394 & 32 \\
\hline Total biaya tetap & 69.368 .910 & & 50.252 .794 & \\
\hline \multicolumn{5}{|l|}{ B. Biaya Variabel } \\
\hline - Bibit & 44.909 .913 & 23 & 31.356 .000 & 20 \\
\hline - $\quad$ Pupuk kandang & 9.794 .000 & 5 & 6.006 .000 & 4 \\
\hline - Pupuk sintetis & 7.649 .446 & 4 & 10.035 .994 & 7 \\
\hline - Pestisida & 9.769 .373 & 5 & 5.719 .989 & 4 \\
\hline $\begin{array}{ll}\text { - } & \text { Tenaga dalam } \\
\text { Keluarga }\end{array}$ & 30.212 .000 & 15 & 46.800 .000 & 30 \\
\hline $\begin{array}{ll}\text { - } & \text { Tenaga kerja } \\
& \text { luar keluarga }\end{array}$ & 22.483 .770 & 11 & 0 & 0 \\
\hline - Kapur & 1.725 .013 & 0,8 & 468.000 & 0,4 \\
\hline Listrik & 4.233 .000 & 2 & 2.859 .994 & 2 \\
\hline Total biaya variabel & 130.776 .515 & & 103.245.977 & \\
\hline Total biaya usahatani & 200.145 .425 & 100 & 153.498 .771 & 100 \\
\hline
\end{tabular}

Sumber: Data primer yang telah diolah, (2019) 
Berdasarkan pada tabel diatas diketahui total biaya dari anggota kelompok tani sebesar Rp 200.145.425 / ha dan bukan anggota kelompok tani sebesar Rp 153.498.771/ ha/. Menurut Soekartawi (2006), total biaya dalam usahatani bunga potong krisan dihitung dengan cara menjumlahkan total biaya tetap satu musim tanam selama empat bulan dan total biaya variabel satu musim tanam selama empat bulan. Tetapi dalam penelitian yang dilakukan biaya tetap dan biaya variabel diambil dalam kangka waktu satu tahun dikarenakan tidak semua petani

Tabel 3.Penerimaan Petani Bunga Potong Krisan

\begin{tabular}{ccc}
\hline Uraian & Anggota & Bukan Anggota Kelompok Tani \\
& Kelompok Tani & \\
\hline Hasil panen (Ikat/ha) & $29.597,8$ & $22.978,8$ \\
Hargajual/ikat (Rp) & 14.222 & 13.333 \\
Penerimaan (Rp) & 420.939 .911 & 306.376 .340 \\
\hline
\end{tabular}

Sumber: Data primer yang telah diolah, (2019)

\section{Pendapatan Usahatani Bunga Potong Krisan}

Dalam penelitian ini pendapatan petani dapat dilihat pada Tabel 4

Tabel 4. Pendapatan Petani Bunga Potong Krisan

\begin{tabular}{lcc}
\hline \multicolumn{1}{c}{ Uraian } & $\begin{array}{c}\text { Anggota Kelompok } \\
\text { Tani }\end{array}$ & $\begin{array}{c}\text { Bukan Anggota } \\
\text { Kelompok Tani }\end{array}$ \\
\hline Penerimaan usahatani (Rp/ha) & 420.939 .911 & 306.376 .340 \\
Biaya total usahatani (Rp/ha) & 200.145 .425 & 153.498 .771 \\
Pendapatan (Rp/ha) & 220.794 .486 & 152.877 .569 \\
\hline
\end{tabular}

Sumber: Data primer yang telah diolah, (2019)

Berdasarkan tabel diatas diketahui pendapatan rata-rata anggota kelompok tani bunga potong krisan sebesar Rp 220.794.486 /ha dan bukan anggota kelompok tani sebesar Rp 152.877.569/ha Menurut Soekartawi (1991), total pendapatan dari usahatani diperoleh dari total penerimaan dikurangi dengan total biaya dalam suatu proses produksi.

Dari hasil penelitian diperoleh nilai $\mathrm{R} / \mathrm{C}$ Ratio dari anggota dan bukan kelompok tani. Nilai R/C Ratio anggota kelompok tani menanam bunga krisan selama empat bulam atau setahun tiga kali tetapi ada juga petani yang menanam satu tahun dua kali tanam.

\section{Penerimaan Usahatani}

Penerimaan adalah perkalian antara produksi yang diperoleh dengan harga jual produk tersebut. Berdasarkan hasil penelitian penerimaan petani bunga potong krisan anggota kelompok tani dan bukan kelompok tani dalam jangka waktu satu tahun dapat dilihat pada Tabel 3. 
Tabel 5. Hasil Uji Regresi Linier Berganda

\begin{tabular}{llccl}
\hline \multicolumn{1}{c}{ Variable } & \multicolumn{1}{c}{ Coefficient } & t-statistik & Probability & \multicolumn{1}{c}{ Keterangan } \\
\hline Keanggotaan/Bukan & $-20772636,09$ & $-1,250$ & 0,222 & Tidak signifikan \\
kelompok tani (X1) & & & & \\
Luas lahan (X2) & 90848,575 & 13,725 & 0,000 & Signifikan \\
Harga jual (X3) & 6730,155 & 3,763 & 0,001 & Signifikan \\
Tingkat pendidikan (X4) & $-8490233,106$ & $-1,251$ & 0,222 & Tidak signifikan \\
Jumlah tenaga kerja (X5) & 591494,034 & 0,128 & 0,899 & Tidak signifikan \\
Julah anggota keluarga & 2055533,547 & 0,376 & 0,710 & Tidak signifikan \\
(X6) & & & & \\
Constant $=-66897876,05$ & & & & \\
F-hitung $=57,923$ & & & \\
F- tabel $=2,46$ & & & & \\
$\mathrm{R}^{2} \quad=0,930$ & & & & \\
\hline
\end{tabular}

*) Signifikan

Sumber : Data primer yang diolah menggunakan spss 20, (2019)

Dari tabel diatas dapat diketahui model persamaan regresi linier berganda, sebagai berikut :

$\mathrm{Y}=-66897876,05-20772636,09 \mathrm{X}_{1}+90848,575 \mathrm{X}_{2}{ }^{*}+6730,155 \mathrm{X}_{3}{ }^{*}$ $-8490233,106 \mathrm{X}_{4}+591494,034 \mathrm{X}_{5}+2055533,547 \mathrm{X}_{6}$

\section{Uji Hipotesis}

\section{Uji Parsial (Uji T)}

Berdasarkan data yang diperoleh dapat diketahui nilai t-tabel dengan taraf kepercayaan sebesar $95 \%(\alpha=5 \%)$ adalah 2,056. Berdasarkan hasil output diketahui anggota kelompok tani dan bukan anggota kelompok tani $\left(\mathrm{X}_{1}\right)$, Tingkat pendidika $\left(\mathrm{X}_{4}\right)$, Jumlah Tenaga Kerja $\left(\mathrm{X}_{5}\right)$, Jumlah Anggota keluarga $\left(\mathrm{X}_{6}\right)$ secara parsial tidak berpengaruh terhadap pendapatan petani bunga potong krisan (Y). Sedangkan Luas lahan $\left(\mathrm{X}_{2}\right)$ dan Harga Jual $\left(\mathrm{X}_{3}\right)$ secara parsial berpengaruh terhadap pendapatan petani bunga potong krisan (Y).

\section{Uji Simultan (Uji F)}

Berdasarkan data yang diperoleh diketahui nilai f-tabel pada taraf kepercayaan $95 \%(\alpha=5 \%)$ adalah 2,46, dapat disimpulkan bahwa model yang digunakan dalam penelitian ini adalah layak digunakan untuk menjelaskan perubahan variabel keanggotaan kelompok tani maupun bukan kelompok tani $\left(\mathrm{X}_{1}\right)$, luas lahan $\left(\mathrm{X}_{2}\right)$, harga jual $\left(X_{3}\right)$, tingkat pendidikan $\left(X_{4}\right)$, jumlah tenaga kerja $\left(\mathrm{X}_{5}\right)$ dan jumlah anggota keluarga $\left(\mathrm{X}_{6}\right)$ secara bersama-sama berpengaruh signifikan terhadap pendapatan petani bunga potong krisan (Y).

\section{Koefisien Determinasi $\left(\mathbf{R}^{\mathbf{2}}\right)$}

Berdasarkan hasil output diketahui nilai koefisien determinasi $\left(\mathrm{R}^{2}\right)$ sebesar 0,930 hal ini mengandung arti bahwa variabel $\mathrm{X}_{1}, \mathrm{X}_{2}$, $\mathrm{X}_{3}, \mathrm{X}_{4}, \mathrm{X}_{5}, \mathrm{X}_{6}$ secara simultan (bersama sama) berpengaruh terhadap variabel $\mathrm{Y}$ sebesar $93 \%$ sedangkan sisanya $7 \%$ dipengaruhi oleh variabel lain (diluar variabel independen).

\section{Uji Asumsi Klasik \\ Uji Normalitas}

Menurut (Ghozali 2016), uji normalitas dilakukan untuk menguji apakah dalam model regresi variabel independen dan variabel dependen atau keduanya mempunyai distribusi normal atau tidak. Berdasarkan hasil uji normalitas yang dilakukan dalam penelitian ini diketahui nilai rasio skewness dan rasio kurtosis berada diantara -2 hingga +2 maka dapat disimpilkan bahwa distribusi data adalah normal 
Tabel 6. Output Uji Normalitas

\begin{tabular}{lcccc}
\hline & \multicolumn{2}{c}{ Skewness } & \multicolumn{2}{c}{ Kurtosis } \\
& Statistic & Std. Error & Statistic & Std. Error \\
\hline Unstandardized Residual & -.428 & .409 & 1.117 & .798 \\
Valid N (listwise) & & & & \\
\hline
\end{tabular}

Sumber: Data primer yang diolah menggunakan SPSS 20, 2019

\section{Uji Multikolinieritas}

Uji multikolinieritas digunakan untuk mengetahui apakah model memiliki gejala multikolinieritas dengan cara VIF yaitu dengan hanya melihat apakah nilai VIF masing-masing variabel lebih dari 10 atau tidak. Bila nilai VIF lebih besar dari 10 maka diindikasikan model memiliki gejala multikolinieritas (Santoso, 2000). Berdasaran uji multikolinieritas dalam penelitian ini diketahui masing-masing variabel memiliki nilai VIF kurang dari 10. Sehingga dapat disimpulkan bahwa model bebas dari mulltikolinieritas.

\section{Uji Heteroskedastisitas}

Uji heteroskedastisitas digunakan untuk melihat apakah model terdapat masalah heteroskedastisitas atau tidak. Berdasarkan uji yang telah dilakukan diketahui terdapat variabel penjelas dengan nilai $t_{\text {hitung }} 2,813>$ $t_{\text {tabel }} 2,056$ dan nilai signifikansi $0,009<0,05$ sehingga dapat disimpulkan bahwa model terjadi masalah heteroskedastisitas.

\section{Uji Autokorelasi}

Uji autokorelasi digunakan untuk mendeteksi adanya penyimpangan autokorelasi atau tidak. Berdasarkan hasil uji Durbin Watson diketahui nilai DW 1,741 dan nilai dL sebesar 1,0607 dan untuk nilai dU sebesar 1,8999 maka dapat disimpulkan bahwa model tidak dapat disimpulkan karena nilai dw berada di antara dl dan du.

Faktor - Faktor Yang Mempengaruhi Pendapatan Petani Bunga Potong Krisan Anggota Kelompok Tani dan Bukan Anggota Kelompok Tani

Faktor - faktor yang digunakan dalam penelitian tidak semua berpengaruh terhadap pendapatan petani, hal tersebut tentu didukung dengan dasar - dasar teori oleh para ahli maupun penelitian terdahulu. Berikut uraian faktor - faktor yang menjadi variabel $(\mathrm{X})$ dalam penelitian :

a. Pengaruh Keanggotaan / Bukan Anggota Kelompok Tani $\left(\mathrm{X}_{1}\right)$ terhadap Pendapatan Petani (Y)

Berdasarkan Tabel 5 diketahui keanggotaan kelompok tani/bukan anggota kelompok tani $\left(\mathrm{X}_{1}\right)$ tidak berpengaruh terhadap pendapatan petani (Y) hasil tersebut diketahui dari nilai probabilitas $0,222>0,05$. Penelitian ini mengambil responden berjumlah 30 orang yang tergabung dalam kelompok tani dan 3 orang bukan anggota kelompok tani yang digunakan sebagai pembanding.

Pada kenyataan dilapangan alasan beberapa petani yang menjadi anggota kelompok tani sebagian adalah "warisan" yaitu dari orang tua diturunkan kepada anaknya sebagai anggota kelompok tani. Alasan lain dibalik keikutsertaan sebagai anggota kelompok tani yaitu untuk memudahkan petani mendapatkan pupuk bersubsidi dengan harga yang lebih murah untuk proses budidaya bunga potong krisan dan juga mempermudah mendapatkan pinjaman, dan juga digunakan sebagai wadah utuk memperoleh pengetahuan dan pengalaman dalam usahatani bunga potong krisan. Hal ini berbanding terbalik dengan hasil penelitian Meira Dewi (2011) yang menyatakan bahwa keanggotaan kelompok tani dapat meningkatkan pendapatan anggota kelompok tani.

b. Pengaruh Luas lahan $\left(\mathrm{X}_{2}\right)$ terhadap Pendapatan Petani (Y)

Berdasarkan pada Tabel 5 diketahui luas lahan $\left(\mathrm{X}_{2}\right)$ berpengaruh nyata terhadap pendapatan petani (Y) bunga potong krisan. 
Kesimpulan tersebut diketahui dari nilai probabilitas $0,000<0,05$. Kondisi lahan di Kecamatan Bandungan sangat cocok digunakan sebagai lahan pertanian karena lokasi berada di lereng Gunung Ungaran dengan ketinggian 831 mdpl yang mendukung perkembangan usahatani bunga potong krisan di wilayah Kecamatan Bandungan. Semakin luas lahan pertanian yang digarap maka semakin besar pendapatan petani bunga potong krisan.

Menurut Suratiyah (2015), semakin luas lahan yang digunakan maka semakin tinggi produksi dan pendapatan per satuan luas. Luas lahan yang diusahakan merupakan variabel bebas yang paling berpengaruh terhadap pendapatan petani bunga potong krisan. Selaras dengan penelitian Kusumaningtyas (2019).

c. Pengaruh Harga Jual $\left(\mathrm{X}_{3}\right)$ terhadap Pendapatan Petani (Y)

Berdasarkan pada Tabel 5 diketahui harga jual $\left(\mathrm{X}_{3}\right)$ berpengaruh nyata terhadap pendapatan petani (Y) dengan nilai probabilitas $0,001<0,05$. Menurut Suratiyah (2015), jika permintaan akan produksi tinggi maka harga ditingkat petani tinggi pula sehingga dengan biaya yang sama petani akan memperoleh pendapatan yang tinggi pula. Hal ini berbading terbalik dengan penelitian Kusumaningtyas (2019) yang menyatakan harga jual tidak berpegaruh nyata karena harga jual yang tinggi di barengi dengan biaya yang tinggi.

d. Pengaruh Tingkat Pendidikan $\left(\mathrm{X}_{4}\right)$ terhadap Pendapatan Petani (Y)

Berdasarkan pada Tabel 5 bahwa tingkat oendidikan $\left(\mathrm{X}_{4}\right)$ tidak berpengaruh nyata terhadap pendapatan petani (Y) dilihat dari nilai probabilitas $0,222>0,05$. Pendidikan petani tidak berpengaruh nyata terhadap pendapatan petani bunga potong krisan karena pendidikan yang dimaksud dalam penelitian ini adalah pendidikan formal. Selain itu, sebagian besar tingkat pendidikan formal petani bunga potong krisan rendah.
Menurut Suratiyah (2015), bahwa pendidikan terutama pendidikan nonformal seperti kursus kelompok tani, penyuluhan, dan studi banding akan menambah pengetahuan dan ketrampilan petani dalam mengelola usahatani. Sejalan dengan penelitian Kusumaningtyas (2019) bahawa pendidikan formal tidak berpengaruh nyata terhadap pendapatan petani.

e. Pengaruh Jumlah Tenaga Kerja $\left(X_{5}\right)$ tehadap Pendapatan Petani (Y)

Berdasarkan pada Tabel 5 jumlah tenaga kerja $\left(\mathrm{X}_{5}\right)$ tidak berpengaruh nyata terhadap pendapatan petani (Y) bunga potong krisan dengan nilai probabilitas $0,899>0,05$. Jumlah tenaga kerja yang dimaksud dalam penelitian ini adalah tenaga kerja dalam keluarga dan tenaga kerja dari luar keluarga.

Menurut Suratiyah (2015), banyak sedikitnya tenaga kerja yang diperlukan dalam usahatani tergantung dari jenis tanaman yang diusahakan. Penambahan jumlah tenaga kerja luar keluarga akan menambah pula biaya yang dikeluarkan petani sehingga biaya yang dikeluarkan oleh petani untuk tenaga kerja akan semakin meningkat sehingga dapat mengurangi pendapatan petani.

f. Pengaruh Jumlah Anggota Keluarga $\left(\mathrm{X}_{6}\right)$ terhadap Pendapatan Petani (Y)

Berdasarkan tabel 15 jumlah anggota keluarga $\left(\mathrm{X}_{6}\right)$ tidak berpengaruh nyata terhadap pendapatan petani (Y) bunga potong krisan dengan nilai probabilitas $0,710>0,05$. Menurut Asih (2009), semakin banyak anggota keluarga yang aktif dalam kegiatan usahatani, berpeluang memperoleh pendapatan yang lebih tinggi dari daripada petani lain dengan jumlah anggota keluarga yang tidak aktif. Pada penelitian ini jumlah anggota keluarga tidak berpengaruh nyata terhadap pendapatan petani bunga potong krisan di Kecamatan Bandungan. Hal ini karena, jumlah anggota keluarga yang terlibat dalam budidaya bunga potong krisan adalah istri petani sedangkan anak-anak dari petani yang sudah remaja 
sampai dewasa bekerja dibidang lain (bukan bertani) dan juga anak-anak petani yang masih kecil dianggap belum mampu melakukan pekerjaan dalam budidaya bunga potong krisan. Penelitian ini didukung dengan penelitian Kusumaningtyas (2019), menyatakan bahwa hubungan jumlah tanggungan keluarga dengan pendapatan tidak signifikan.

\section{KESIMPULAN}

1. Pendapatan yang diterima oleh petani bunga potong krisan dalam jangka waktu satu tahun yaitu untuk anggota kelompok tani sebesar Rp 220.794.486/ ha dan bukan angggota kelompok tani sebesar Rp 152.877.569/ha.

2. Faktor-faktor yang mempengaruhi pendapatan petani bunga potong krisan baik anggota kelompok tani dan buka kelompok tani yaitu luas lahan $\left(\mathrm{m}^{2}\right)$ dan harga jual (Rp) bunga potong krisan, untuk faktor keanggotaan kelompok tani dan bukan anggota kelompok tani, tingkat pendidikan, jumlah tenaga kerja dan jumlah anggota keluarga tidak berpengaruh secara nyeta terhadap pendapatan petani bunga potong krisan di Dusun Clapar Desa Duren Kecamatan Bandungan Kabupaten Semarang.

\section{UCAPAN TERIMAKASIH}

Penulis mengucapkan terimakasih kepada pihak-pihak terkait yang telah membantu penulis dalam penyelesaian penelitian dan penyusunan jurnal. Terimakasih kepada petani bunga potong krisan di Dusun Clapar Desa Duren Kecamatan Bandungan yang telah bersedia dilibatkan menjadi responden dalam penelitian ini sehingga penulis terbantu dalam melengkapi data-data yang dibutuhkan dalam menyusun jurnal. Bapak, ibu serta keluarga yang telah memberi dukungan dengan doa, moral maupun materi sehingga penulis dapat menyelesaikan segala persoalan selama proses penulisan jurnal serta teman-teman dansemua pihak yang turut memberi dukungan dan membantu dalam penyelesaian jurnal.

\section{DAFTAR PUSTAKA}

Asih, D. N. 2009. Analisis Karakteristik dan Tingkat Pendapatan Usahatani Bawang Merah di Sulawesi Tengah, Jurnal Agroland 1 (16)

Badan Pusat Statistik Provinsi Jawa Tengah. 2016. Statistik Hortikultura. Jawa Tengah :BPS

Badan Pusat Statistik Kabupaten Semarang. 2016. Statistik Hortikultura. Kabupaten Semarang

Ghozali, I. 2016. Aplikasi Analisis Multivariate dengan Program IBM SPSS 23. Universitas Diponegoro. Semarang.

Janie, Dyah Nirmala Arum. 2012. Statistik Deskriptif \& Regresi Linear Berganda Dengan SPSS. University Press. Semarang

Kusumaningtyas, Y. I. et, al. 2019. Jurnal Analisis Faktor Sosial Ekonomi Yang Mempengaruhi Pendapatan Petani Bunga Potong Krisan (Studi Kasus : Kecamatan Bandungan Kabupaten Semarang). Universitas Sebelas Maret. Surakarta.

Lukito, A.M. 1998. Rekayasa Pembangunan Krisan dan Bunga lain. Trubus. Jakarta.

Meira Dewi, 2011. Jurnal Pengaruh Usaha Kelompok Wanita Tani "MEKAR USAHA" Terhadap Pendapatan Keluarga (Studi Kasus: Desa Budakeling , Kecamatan Bebandem, Kabupaten Karangasem).Universitas Pendidikan Ganesha Singaraja. Indonesia. 
Santoso, Singgih. 2000. Mengolah Data Statistik secara Profesional. Elex Media Komputindo. Jakarta.

Soekartawi et,al. 1986. Ilmu Usahatani dan Peelitian Ilmu Untuk Pengembangan Petani Kecil. UI-Press. Jakarta.

Soekartawi. 1991. Agribisnis, Teori dan Aplikasinya. CV Rajawali. Jakarta.

Soekartawi. 2006. Analisis Usahatani. Universitas Indonesia. Jakarta
Sugiyono. 2012. Statistika untuk Penelitian. Alfabeta. Bandung.

Suratiyah, K. 2015. Ilmu Usaha Tani (Edisi Revisi). Penebar Swadaya. Jakarta.

Widyawan dan Prahastuti. 1994. Bunga Potong : Tinjauan Litelatur. PDII. Jakarta.

Sugiyono. 2008. Metode Penelitian Kuantitatif Kualitatif dan $R \& D$. Alfabeta. Bandung 